\title{
Effect of Rock Fragments on Tracer Transport in Broadleaved and Coniferous Forest Soils: Column Study
}

\author{
Pascal Nsengumuremyi ${ }^{1,2}$, Junfang Cui ${ }^{*}$, Ruxin Yang1,2 \\ ${ }^{1}$ Key Laboratory of Mountain Surface Processes and Ecological Regulation, Institute of Mountain Hazards and Environment, \\ Chinese Academy of Sciences, Chengdu, China \\ ${ }^{2}$ University of Chinese Academy of Sciences, Beijing, China \\ Email: ^jfcui@imde.ac.cn
}

How to cite this paper: Nsengumuremyi, P., Cui, J.F. and Yang, R.X. (2021) Effect of Rock Fragments on Tracer Transport in Broadleaved and Coniferous Forest Soils: Column Study. Journal of Water Resource and Protection, 13, 198-215.

https://doi.org/10.4236/jwarp.2021.133012

Received: January 28, 2021

Accepted: March 9, 2021

Published: March 12, 2021

Copyright (c) 2021 by author(s) and Scientific Research Publishing Inc. This work is licensed under the Creative Commons Attribution International License (CC BY 4.0).

http://creativecommons.org/licenses/by/4.0/

\begin{abstract}
This study investigated the effect of rock fragments on tracer transport in broadleaved and coniferous forest soils from the $0-100 \mathrm{~cm}$ depth of Gongga Mountain in eastern margin of Qinghai Tibetan Plateau. Using repacked soil columns $(20 \mathrm{~cm}$ in height and $10 \mathrm{~cm}$ in diameter) with different rock fragments contents $(0 \%, 5 \%$, and $15 \%$ in $\mathrm{v} / \mathrm{v})$, breakthrough curves of bromide (as non-reactive tracer) were obtained under saturated condition. A two-region model was applied and the parameters were estimated by inverse modeling. Results show that with increasing rock fragment content the dispersivity $(\lambda)$ generally increased while the mobile-immobile partition coefficient $(\beta)$ and the mass transfer coefficient $(\omega)$ decreased. The presence of rock fragments led to an increase in the fraction of immobile domain as well as soil tortuosity. A plausible explanation is that the soil beneath the rock fragments behaved as immobile domain and soil-rock interfaces could serve as preferential flow paths.
\end{abstract}

\section{Keywords}

Rock Fragments, Forest Soil, Tracer Transport, Breakthrough Curve, Bromide

\section{Introduction}

Transport evaluation of contaminants through porous media is essential to determine accurately the contamination in soils and aquifers. The movement of water and solutes in vadose zone can be restricted by preferential flow and affect flow patterns in soil [1] [2]. In forest stony soil, preferential flow and transport 
can be impacted by several influencing factors, which include physical and chemical properties of soil, structure development of soil, rock fragments (gravel, stones, boulders, etc.), land and vegetation cover, as well as hillslope gradient [3]. Besides, Zhang et al. [4] reviewed the network of macropores created by rock fragments and plant roots, and its significant impact on vertical water movement in soil profile. Though contribution of macropores is a small fraction to total soil porosity, it plays an essential role in preferential flow in vadose zone [5] [6]. Due to the mixture of soil and rock fragments, preferential flow paths exert influences on soil hydrological processes [7].

Torri et al. [8] defined rock fragments content as a percentage, either by volume or by mass. Around the world, soils containing high rock fragment are widespread [9]. For example, in Western Europe, rock fragment content occupies for about 30\% of the land area [9]. According to Poesen and Lavee1 [10] and Cousin et al. [11], land area of Mediterranean zone accounting more than $60 \%$ of rock fragments content. As stated by several studies, rocky soils are prevalent also in mountainous areas of China. For instance, mountain meadows around Beijing, rock fragments content accounts for more than $22 \%$ on the surface of the coarse brown soil [12]. Additionally, content of rock fragments at soil depth of 0 to $30 \mathrm{~cm}$ in the Gongga mountain of Sichuan province is higher than $18.22 \%[13]$.

According to several authors, it was revealed that rock fragments had influence on physical and hydraulic properties of soil. For instance, rock fragments increase the soil aggregate stability and reinforce the surrounding soil matrix [14]. To study the correlation between number density of macropores and the number of rock fragments in different forest stony soils in mountain area, upper soil layer of $0-10 \mathrm{~cm}$ showed significant negative correlation, however, there was not significant correlation in lower soil layers of $10-20 \mathrm{~cm}$ and $20-30 \mathrm{~cm}$ as well [15]. For rock fragments content less than $40 \%(w / w)$, Zhou et al. [16] found that solute transportation was more evident in soil columns containing rock fragments than columns without rock fragments. According to Novák and Hlaváčiková [17], the presence of gravels and stones in soil can affect the soil hydraulic conductivity by reducing the effective cross-sectional area through which water flows, and an increase in stoniness is codetermined in greater curvatures of flow paths. Additionally, the shrink-swell phenomena may create lacunar pores, and the effect of increasing tortuosity can be counterbalanced. In some studies, the effect of rock fragments on soil hydraulic properties showed conflicting results. For instance; according to Beckers et al. [18], soil preferential flow increasing with rock fragment content, but differently to this, Novák et al. [19] reported negative correlation of saturated hydraulic conductivity with rock fragment content. In forest soil, Schulin et al. [20] investigated the solute transport by using different rock fragments contents and could get smooth breakthrough curves. In addition to the content, Zhang et al. [3] reviewed the impact of sizes, positions and shapes of rock fragments on soil hydraulic processes.

Many researchers studied solute transport, solute mass flows, and water flow 
in soil, so that they investigated hydrological processes along rock-soil interfaces by using different experimental methods such as laboratory experiments [21] [22] [23], modeling [24]-[31], tracer experiments [32] [33] [34] [35] [36], radar tomography [37] and numerical simulation [38] [39] [40] [41] [42].

Bromide tracer is commonly used to investigate the water moving or solute transported in soil column because of its mass conservation. From invasion simulation, essential solute transport parameters can be calculated such as the diffusion coefficient, the mobile water fraction and mass transfer in the soil column. Furthermore, $\mathrm{Cl}^{-}$is also used as a non-reactive tracer in some columns studies to explore the impact of rock fragments [16] [43]. But, $\mathrm{Br}^{-}$is advantageous because it is not involved in the hydro-geochemical and bio-chemical processes of the soil, so that, these behaviors enable it to trace the transport processes at a low concentration [44]. In general, $\mathrm{Br}^{-}$and $\mathrm{Cl}^{-}$tracers behave similarly, but $\mathrm{Cl}^{-}$is ubiquitous in the environments.

Two region-model is common model used in tracer transport prediction in soil containing rock fragments. For example, Zhou et al. [16] and Zhou et al. [43] used both equilibrium and non equilibrium Convection Dispersion Equation (Two-region) models to predict solute transport in columns containing different contents and sizes of gravels to obtain dispersivity, fraction of mobile water and diffusive mass transfer coefficient. According to van Genuchten and Wierenga [45], the-two region model supposes the liquid portion to be divided into two regions including a mobile region, in which movement of water can be restricted, and an immobile region in which water movement cannot be occurred. A simple model is often found to be inadequate to simulate the breakthrough curves because uncertainty in parameter estimates can be large, while the observations are adequately matched by more complex model [46].

Even though stony soils occur in many forested areas, the influence of the rock fragments presence on hydraulic properties of soils is still often neglected [17]. The evaluation of hydrological responses of stony soils has been hampered by difficulties related with the mechanisms of soil preferential flow. For stony forest soils, rock fragments content estimation remains complicated in situ. Even though the mass of rock fragments in forest soil is moderately easy to measure, it is difficult and challenging to determine accurately the volume of rock fragments. Forest soil layers under broad-leaved and coniferous trees on Gongga Mountain are composed of mineral soil, rock fragments, water, and amount of plant roots systems. Particularly, the relation of rock fragments to preferential flow and transport tends to be more complicated in forest soils containing abundant large plant roots systems. Rock fragments parameters; particularly content and size, have increased interests in forest ecosystems because of their role in affecting the soil water flow and solute transport. Repacking columns with sieved soil afford homogeneous physical soil conditions. Therefore, by using repacked soils, the sole-impact of rock fragments content on tracer transport in forest soil can be investigated accurately. 
To date, little has been known about the impact of rock fragments on solute transport in forest soils. The high concentration of pollutants (such as; pesticides, soluble fertilizers, land-applied municipal wastes) in groundwater is closely related to the preferential flow and transport. Given the known relations between hydrological processes and the groundwater pollution, this study explores the influence of rock fragments in soils under broadleaved and coniferous forests of Mountain Gongga. The purpose of this study was to investigate the effects of rock fragments content on solute transport in forest soil.

\section{Material and Methods}

\subsection{Study Site}

The field study was carried out on the eastern slopes of Mountain Gongga under broadleaved $\left(29^{\circ} 59^{\prime} 47^{\prime \prime} \mathrm{N}, 102^{\circ} 04^{\prime} 83^{\prime \prime} \mathrm{E}\right)$ and coniferous forests $\left(29^{\circ} 57^{\prime} 12^{\prime \prime} \mathrm{N}, 101^{\circ}\right.$ 99'23"E) which are located in eastern margin of Qinghai-Tibetan plateau, China. Broad-leaved forest (2259 a.s.l) and coniferous forest (3067 m a.s.l), as two typical forests ecosystems were selected [Figure 1]. The dominate tree species in broad-leaved forest are Hippophaerha., Betula utilis, T. chinen., B. albo., L. glabra, and $P$. chinensis, and they are $R$. villosam, Q. aquifol, A. squam., A. forre., A. georgei, P. balfo., Picea libian, Pinus densata, and Rh. Faberi in coniferous forest.

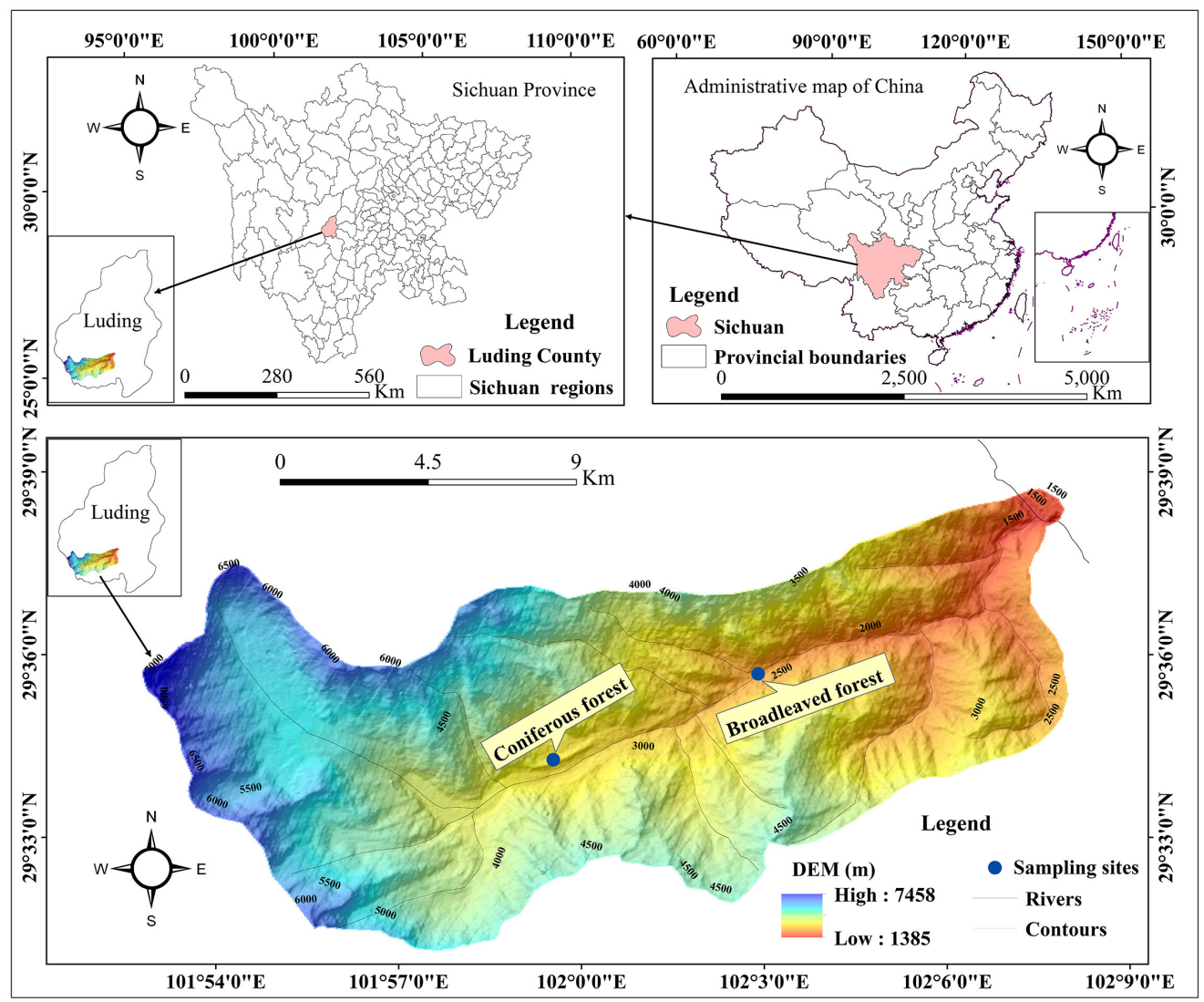

Figure 1. Location of the study area. 
The main climatic characteristics of the Gongga mountain are an average annual temperature and mean annual precipitation of $12.7^{\circ} \mathrm{C}$ and $1050.3 \mathrm{~mm}$ at $1600 \mathrm{~m}$ a.s.l. (from 1992 to 2010 ) and $4.2^{\circ} \mathrm{C}$ and $1947.4 \mathrm{~mm}$ at $3000 \mathrm{~m}$ a.s.l. (from 1988 to 2010), respectively [47]. According to Wu et al. [48], the wet season of Mountain Gongga is from May to October, in which the total annual precipitation accounts for $86.9 \%$ at $1600 \mathrm{~m}$ and $79.7 \%$ at 3000 .

\subsection{Soil Sampling and Analysis}

Soil samples were collected at the two forest types (coniferous and broadleaved). A trench with $50 \mathrm{~cm}$ in width, $50 \mathrm{~cm}$ in length and $100 \mathrm{~cm}$ in depth was excavated. Triplicate plots $(20 \mathrm{~m} \times 20 \mathrm{~m}$ each) were chosen for each of selected forest community. In each plot, soil samples were taken at five different locations. Soil samples were collected from two depths of $0-20 \mathrm{~cm}$ and $20-100 \mathrm{~cm}$ at each site. The excavated soils including rock fragments were collected, packed in the bag using shovel and then transported to the laboratory. Soil core samples (5 $\mathrm{cm}$ in height and $5 \mathrm{~cm}$ in diameter) were collected at each depth as well for soil hydraulic property and bulk density measurement.

In laboratory, loose soil was air-dried and sieved by $2 \mathrm{~mm}$ mesh for soil basic analysis and column experiment. To explore the soil physical and chemical properties from our study area, the wet combustion method of Walkley and Black [49] was used to determine soil organic matter (SOM) content. Soil texture was determined by the pipette method [50]. $\mathrm{pH}$ was determined by a standard $\mathrm{pH}$ meter at a 1:5 soil/water ratio [51]. Soil saturated hydraulic conductivity $\left(K_{\text {sat }}\right)$ was measured by falling head method [52] after soil saturated and the result of $K_{\text {sat }}$ was showed as at $10^{\circ} \mathrm{C}$. Saturated soil water content $\left(\theta_{\mathrm{s}}\right)$ was measured by the same soil core. After measurement of $\theta_{\mathrm{s}}$, soil core was oven-dried and weighted, and the volume and weight of gravels ( $>2 \mathrm{~mm}$ in diameter) was measured, thus soil bulk density $\left(\rho_{\mathrm{b}}\right)$ in this study was calculated by subtracting out gravels. Table 1 shows physical and chemical properties of soils from study area.

\subsection{Columns Transport Experiment}

The glass cylindrical columns (20 cm in height and $10 \mathrm{~cm}$ in diameter) were repacked with soils and gravels at different ratios (0\%,5\% and 15\%). Gravels used in this study were in diameter of 1 to $3 \mathrm{~cm}$, which were collected from field. The soils and gravels were weighed and mixed in a plastic container, and filled into the columns. Packing was carried out layer by layer of $3 \mathrm{~cm}$ column height to make sure that rock fragments were uniformly distributed in the column. The air dried soils were shaken to fill up some gaps between rock fragments. $3 \mathrm{~cm}$ layer of quartz sands (particle size between 0.5 and $1.0 \mathrm{~mm}$ ) was layed both above and below of the soil in column as filter layer. Soil columns containing $5 \%$ and $15 \%$ of rock fragments by volume was prepared for the two soil layers (0 20 and $20-100 \mathrm{~cm}$ ) of broadleaved and coniferous forests. 
Table 1. Physical-chemical properties of the soils.

\begin{tabular}{|c|c|c|c|c|c|c|c|c|}
\hline Forest & Depth & Clay & Silt & Sand & SOM & $\rho_{b}$ & $\mathrm{pH}$ & Ksat \\
\hline \multicolumn{9}{|c|}{$(<0.002 \mathrm{~mm})(0.002-0.05 \mathrm{~mm})(0.05-2 \mathrm{~mm})$} \\
\hline & $\mathrm{cm}$ & $\%$ & $\%$ & $\%$ & $\mathrm{~g} \cdot \mathrm{Kg}^{-1}$ & $\mathrm{~g} \cdot \mathrm{cm}^{-3}$ & & $\mathrm{~mm} / \mathrm{min}$ \\
\hline \multirow{2}{*}{ B.F } & $0-20$ & 4.08 & 6.22 & 89.70 & 39.87 & 0.71 & 7.25 & 47.83 \\
\hline & $20-100$ & 1.70 & 5.10 & 93.20 & 13.50 & 1.38 & 6.91 & 17.75 \\
\hline \multirow{2}{*}{ C.F } & $0-20$ & 1.78 & 7.92 & 90.31 & 26.22 & 0.98 & 6.72 & 27.75 \\
\hline & $20-100$ & 1.61 & 6.01 & 92.38 & 15.22 & 1.11 & 6.87 & 11.82 \\
\hline
\end{tabular}

B.F: broadleaved forest; C.F: coniferous forest.

The transport experiment was started by saturating soil columns from the bottom to the top with distilled water. After soil saturation, flow injection direction was changed from the top of the column to the bottom and preferential flow was driven by gravity [Figure 2]. Soil was preconditioned by applying $3 \mathrm{PV}$ (Pore volume) of distilled water, then one pore volume of $\mathrm{KBr}\left(100 \mathrm{mg}-\mathrm{Br}^{-} / \mathrm{L}\right.$ as nonreactive tracer). The steady state flow rate was set to be close to the overall saturated hydraulic conductivity $\left(K_{\text {sat }}\right)$ of each column determined in advance, and controlled by a peristaltic pump. After preconditioning, four pore volumes of $\mathrm{KBr}$ were injected. After that, the inflow solution was switched back to distilled water until there was no $\mathrm{Br}^{-}$in the outflow. The column effluent was periodically collected and then analysed for $\mathrm{Br}^{-}$concentration by ion meter (Bante931-Br Benchtop Bromide Ion Meter, Bante Instrument Co. Ltd). The breakthrough curves (BTCs), expressed as the $\mathrm{Br}^{-}$relative concentration $\left(C / C_{0}\right)$ versus pore volumes $(\mathrm{PV})$ were obtained.

Porosity of the soil in column was calculated as:

$$
\text { Porosity }(\Omega)=1-\frac{\text { Bulk density }}{\text { Particle density }}
$$

where;

Particle density $\left(\rho_{p}\right)=2.65 \mathrm{~g} / \mathrm{cm}^{3}$

\subsection{Model Theory}

The two-region model described accurately the bromide transport process in the soil columns containing either homogeneous soil or soil-rock fragments mixtures. An iteration technique was applied, and lowest residual value for the sum of squares was used. Thus, by using STANMOD software, CXTFIT 2 [53] as code for estimating transport parameters from laboratory experiment produced a relatively realistic fit for all soil columns.

The two-region model assumes the liquid phase to be divided into a mobile and an immobile region [43], and the solute could exchange between those two regions [53]. Bromide concentrations were modeled by using the following expression:

$$
\theta_{m} \frac{\partial C_{m}}{\partial t}+\theta_{i m} \frac{\theta C_{i m}}{\partial t}=\theta_{m} D \frac{\partial^{2} C_{m}}{\partial x^{2}}-v_{m} \theta_{m} \frac{\partial C_{m}}{\partial x}
$$




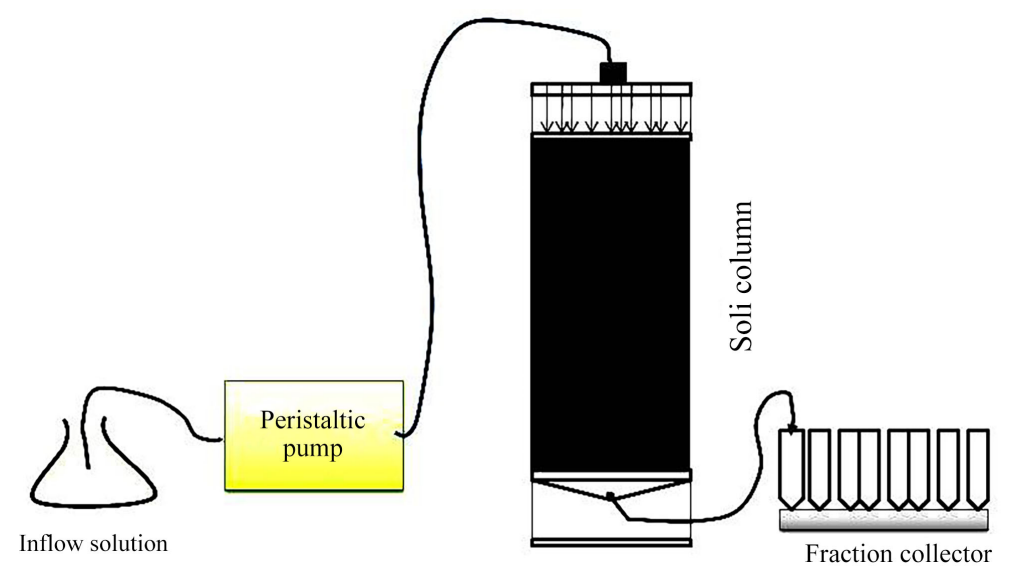

Figure 2. Schematic diagram of the soil column experiment.

$$
\begin{gathered}
\theta_{i m} \frac{\partial C_{m}}{\partial t}=\alpha\left(C_{m}-C_{i m}\right) \\
\theta=\theta_{m}+\theta_{i m}
\end{gathered}
$$

where:

$\theta_{m}=$ the volumetric water content in the mobile region $\left(\mathrm{cm}^{3} / \mathrm{cm}^{3}\right)$

$\theta_{i m}=$ the volumetric water content in the immobile region $\left(\mathrm{cm}^{3} / \mathrm{cm}^{3}\right)$

$C_{m}=$ the concentration in the mobile region $(\mathrm{mg} / \mathrm{L})$

$C_{i m}=$ the concentration in the immobile region $(\mathrm{mg} / \mathrm{L})$

$V_{m}=$ the pore-water velocity in the mobile region $(\mathrm{cm} / \mathrm{h})$

$\alpha=$ the first-order mass transfer coefficient $\left(\mathrm{h}^{-1}\right)$

We assumed that;

$$
\begin{gathered}
C=0 \text { or } C_{m}=0, \text { While } 0<x<1, t=0 \\
\frac{\partial C}{\partial x}=0 \text { or } \frac{\partial C_{m}}{\partial x}=0 ; x=1, t>0
\end{gathered}
$$

The dispersivity, $\lambda(\mathrm{cm})$, for each column was calculated from dispersion coefficient, $D\left(\mathrm{~cm}^{2} / \mathrm{h}\right)$, and pore water velocity, $v(\mathrm{~cm} / \mathrm{h})$, could be written as;

$$
\lambda=\frac{D}{v}
$$

The pore water velocity $(v)$ was calculated from darcy velocity, $q(\mathrm{~cm} / \mathrm{h})$, and porosity, $\Omega$, as;

$$
\begin{aligned}
& v=\frac{q}{\Omega} \\
& q=\frac{Q}{A}
\end{aligned}
$$

where;

$Q=$ the constant discharge rate of the step input $\left(\mathrm{cm}^{3} / \mathrm{h}\right)$

$A=$ the input surface area of the soil column $\left(\mathrm{cm}^{2}\right)$.

The fraction of mobile soil solution, $\phi$, was calculated, and the formular can be written as; 


$$
\phi=\frac{\theta_{m}}{\theta}=\beta R-f(R-1)
$$

where;

$$
\begin{aligned}
& f=\text { the fraction of adsorption sites } \\
& \theta=\text { the total volumetric soil water content } \\
& \beta=\text { the mobile-immobile partition coefficient } \\
& R=\text { the retardation factor. }
\end{aligned}
$$

According to Nkedi-Kizza et al. [54], we approximated, and assumed that $\phi=$ $f$, then we knew the value of the fraction of adsorption sites in the mobile region, thus Equation (10) shows that:

$$
\begin{aligned}
\phi & =\beta \\
\text { And } \beta & =\frac{\theta_{m}}{\theta}
\end{aligned}
$$

The absolute mass transfer coefficient, $\alpha$, was calculated by using this formular

$$
\omega=\frac{\alpha \mathbf{l}}{\boldsymbol{q}}
$$

\section{Results and Discussion}

\subsection{Breakthrough Curves}

The Breakthrough curves for bromide transport in soil and soil-rock fragments mixtures are shown by Figure 3 and Figure 4. Tracer transport processes were firstly investigated by analyzing the breakthrough curves for all columns. To make physical evaluation and comparison of nonlinear least squares estimates, we firstly plotted the observed with predicted data to visibly assess the match.

For all columns, the average bromide recoveries were generally above $93 \%$. The shapes of bromide breakthrough curves were similar for both homogeneous soil columns and soil-rock fragments columns of either $5 \%$ or $15 \%$ content, from the same soil depth. These results agree with other several researchers such as Russo [55] studying on a soil containing 50\% to $70 \%$ (w/w) rock fragments; besides, Zhou et al. [16] and Zhou et al. [43] investigated the soil columns contaminating $10 \%$ to $60 \%(\mathrm{w} / \mathrm{w})$ of gravels, observed similarities of the tracer transport processes between stony soils and their corresponding soils without rock fragments.

According to the data and Figure 3(a), Figure 3(b), and Figure 4(b), it is shown that, at the time which outflow concentration reached the full initial concentration, the number of pore volumes eluted was lower for the soil columns containing $15 \% \mathrm{RFc}$ than the other columns, indicating fast solute transport in the soil containing higher content of rock fragments. Top soil of $0-20 \mathrm{~cm}$ in broadleaved forest [Figure 3(a)] demonstrates that bromide concentrations in the effluent of homogeneous, stainless soil column did not get to the initial concentration even after leaching of three pore volumes, however increased continually over the whole pulse input period. The difference made by rock fragments 
addition in top soil of broadleaved is clear, as the soils containing rock fragments show the maximum bromide concentration before 1 pore volume, and then become constant until $4 \mathrm{PV}$. The rock fragments may increase immobile region in soil for the reason that their relative permeability is very low. Solute transport may be influenced by soil-rock interface pathways. The subsoil $(20-100 \mathrm{~cm})$ from broadleaved soil columns of $15 \%$ shows that concentration of bromide reached the maximum earlier than $0 \%$ and $5 \%$ rock content, besides, initial breakthrough curves of soil-rock is less than soil without rocks with regard to number of pore volumes.

For coniferous forest soil columns, the top soil shows the higher initial breakthrough for 15\% rock than other rock contents. It implies that bromide was detected later in effluent due to rock fragments. The rock fragments may increase the tortuosity, and can enlarge the distance travelled by tracer, and affect the time of leaching. Contrastingly, there was no difference between 5\% rock-soil and stainless soils columns in terms of first bromide detection time, since bromide was detected at $0.0556 \mathrm{PV}$. The sub soil column shows that bromide in $15 \%$ rock-soil was detected earlier, and BTC shows that bromide reach maximum concentration before other columns of lower contents of rocks. These observed differences highlighted the role of rock fragments in soil.
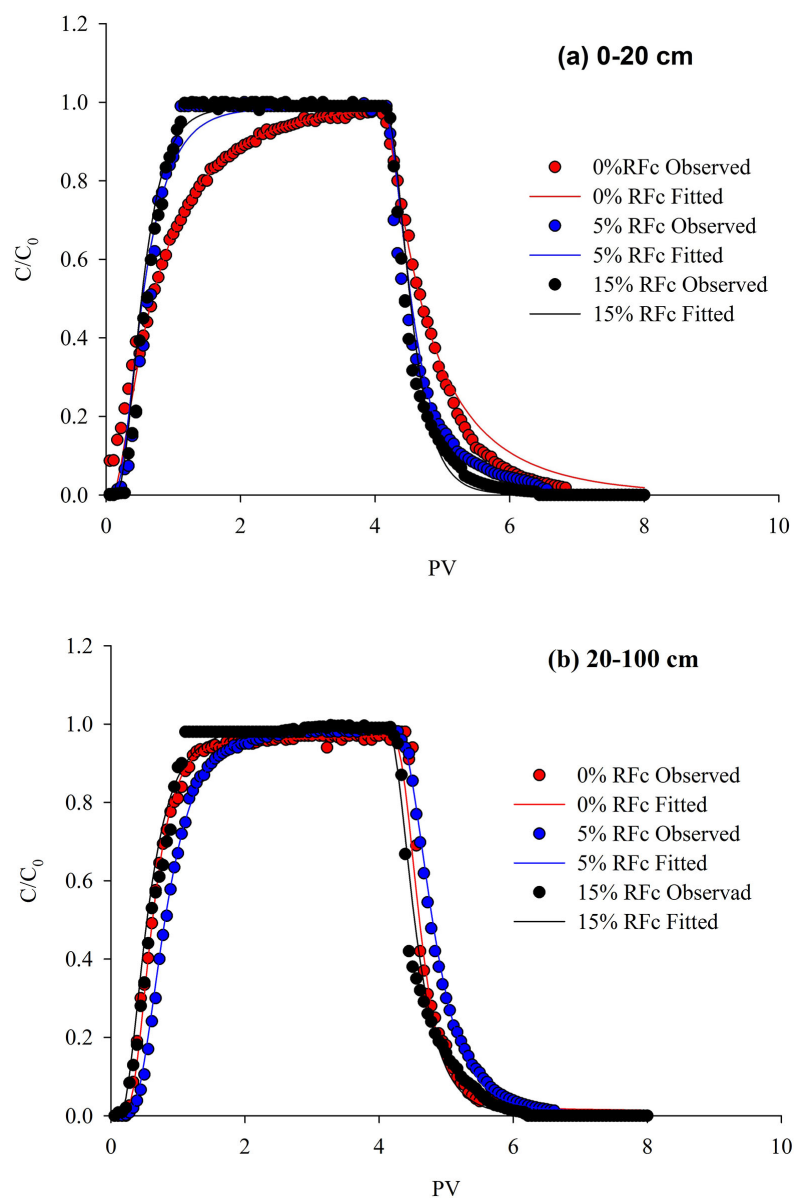

Figure 3. Observed and simulated BTCs of $\mathrm{Br}$ in broadleaved forest. 

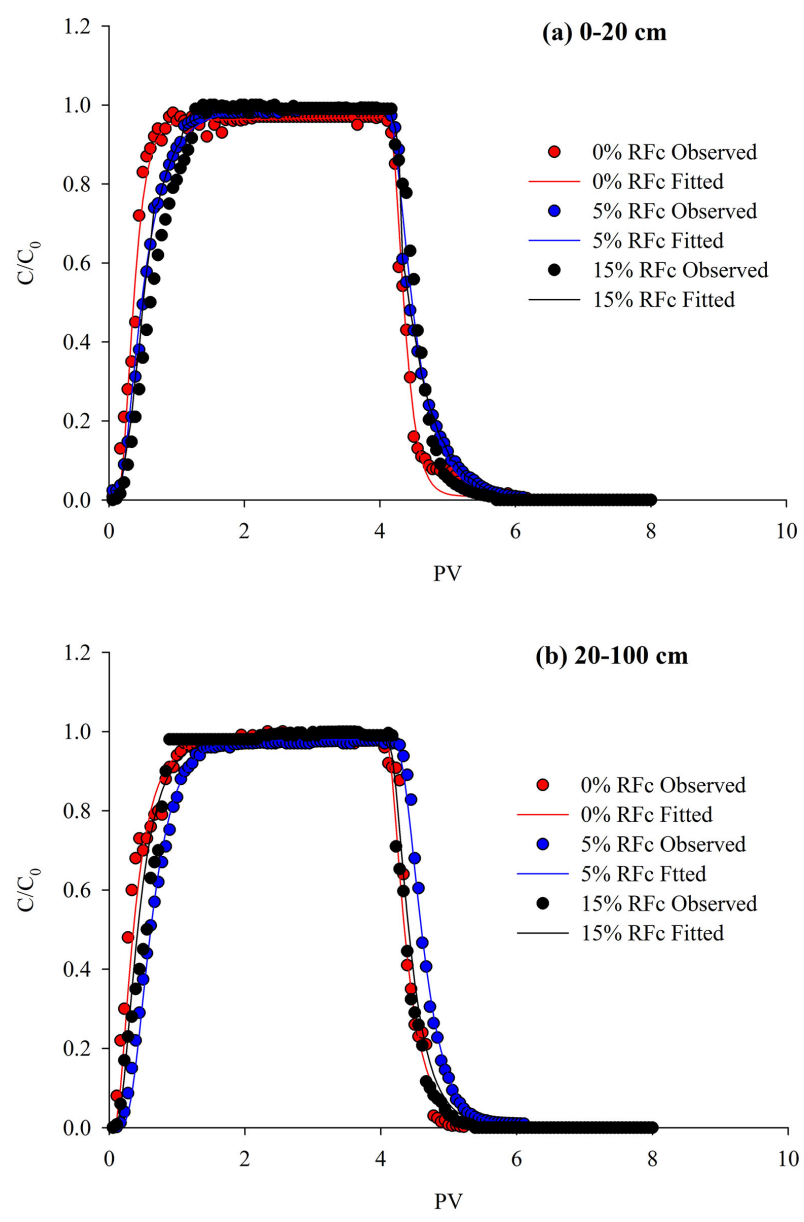

Figure 4. Observed and simulated BTCs of $\mathrm{Br}^{-}$in coniferous forest soil.

BTCs of broad-leaved forest [Figure 3] soil tended to be slightly different when compared to those for coniferous forest soil [Figure 4] with the same rock fragments content and same depth, however, all BTCs displayed symmetry. Since BTCs at Figure 3 showed little extensive tailing compared to Figure 4, it implies fast transport of tracer in soils from coniferous forest, but the difference is not significant.

\subsection{Solute Transport Parameters}

For the identification of multiple processes governing water flow and solute transport in forest soil, it is crucial to quantify reliably the transport parameters from the soil columns experiment. The conceptual processes that underlay the models were verified by the agreement between estimated data and observed data. Furthermore, verification of these processes was validated. The root mean square for error (RMSE) and the square of correlation coefficient $\left(R^{2}\right)$ were calculated to obtain a realistic match of data. Performance of the model for all columns showed that $\mathrm{R}^{2}$ was higher than 0.97 and MSE less than 0.002 .

All two-region model parameters were estimated independently of the BTC simulated data. We used measured data such as the average pore water veloci- 
ty, the retardation factor, solute concentration, and pore volumes. By using STANMOD program, the fitted transport parameters with the CXTFIT 2 were obtained. Table 2 lists the various dispersion coefficients (D), mobile-immobile partition coefficient $(\beta)$ and the mass transfer coefficient $(\omega)$ obtained by fitting the two-region model. Most parameters varied a lot with increasing in rock fragments contents.

\section{DISPERSIVITY $(\lambda)$}

According to fitted results with two-region model [Table 2], for broadleaved forest soil, the dispersivity values from $0-20 \mathrm{~cm}$ soil layer were 1.57, 1.67 and $2.33 \mathrm{~cm}$ for $0 \%, 5 \%$, and $15 \%$ rock fragments contents, respectively, while, 20 100 layer accounted the dispersivity values of $1.66,1.58$ and $2.2 \mathrm{~cm}$, for $0 \%, 5 \%$, and $15 \%$ rock fragments contents, respectively. For coniferous forest, soil from 0 - $20 \mathrm{~cm}$ layer showed the dispersivity values of $1.43,2.17$ and $1.4 \mathrm{~cm}$, whereas 20 - 100 layer showed 1.57, 1 and $2.18 \mathrm{~cm}$ for $0 \%, 5 \%$, and $15 \%$ rock fragments contents, respectively. As indicated by results, using the same soil depth and content of rock fragments, the dispersivity parameter values of broad-leaved soil columns were distinctly different from those of coniferous soil columns.

The dispersivity values in both soil layers of broad-leaved forest and subsoil of coniferous forest show that dispersivity increased due to $15 \%$ rock fragments content in soil columns, however it is different in the column containing topsoil from coniferous forest. In addition, despite the fact that $5 \%$ content of rock fragments in soil column is low, it essentially increased the dispersivity in $0-20$ $\mathrm{cm}$ soil layers of both forests, as shown in Table 2. For the columns of $20-100$ soil layers of both broadleaved and coniferous, the dispersivity values decreased firstly, then increased because of further addition of rock fragments.

Table 2. Estimated transport parameters of $\mathrm{Br}^{-}$.

\begin{tabular}{|c|c|c|c|c|c|c|c|c|}
\hline Forest & Depth & RFc & $\mathrm{V}$ & $\mathrm{D}$ & $\lambda$ & $\beta$ & $\omega$ & $\mathbf{R}^{2}$ \\
\hline & $(\mathrm{cm})$ & (\%) & $(\mathrm{cm} / \mathrm{h})$ & $\left(\mathrm{cm}^{2} / \mathrm{h}\right)$ & $(\mathrm{cm})$ & $(-)$ & $(-)$ & \\
\hline \multirow{6}{*}{ Broadleaved } & & 0 & 1.36 & 2.14 & 1.57 & 0.79 & 0.33 & 0.98 \\
\hline & $0-20$ & 5 & 1.36 & 2.28 & 1.67 & 0.66 & 0.025 & 0.99 \\
\hline & & 15 & 1.36 & 3.18 & 2.33 & 0.62 & 0.019 & 0.99 \\
\hline & & 0 & 2.08 & 3.46 & 1.66 & 0.61 & 0.015 & 0.99 \\
\hline & $20-100$ & 5 & 2.08 & 3.3 & 1.58 & 0.58 & 0.014 & 0.97 \\
\hline & & 15 & 2.08 & 4.58 & 2.2 & 0.42 & 0.011 & 0.98 \\
\hline \multirow{6}{*}{ Coniferous } & & 0 & 1.59 & 2.28 & 1.43 & 0.66 & 0.025 & 0.98 \\
\hline & $0-20$ & 5 & 1.59 & 3.46 & 2.17 & 0.61 & 0.015 & 0.99 \\
\hline & & 15 & 1.59 & 2.23 & 1.4 & 0.39 & 0.038 & 0.99 \\
\hline & & 0 & 1.71 & 2.7 & 1.57 & 0.87 & 0.032 & 0.98 \\
\hline & $20-100$ & 5 & 1.71 & 1.71 & 1 & 0.68 & 0.041 & 0.99 \\
\hline & & 15 & 1.71 & 3.73 & 2.18 & 0.63 & 0.015 & 0.99 \\
\hline
\end{tabular}

RFc: rock fragments content. 
This increasing of dispesivity values due to rock fragments addition in most columns may prove that the solute transport paths in rock-soil mixture columns are much higher torturous than other column. Even though the fact that 5 or $15 \%$ content of rock fragments in soil columns are low, they may essentially enhance the tortuosity of the solute transport since the solute is only transported in region containing mineral soils. Volumetric content of soils that is straightly below the rock fragments might be component of the immobile domain. For that reason, the dispersivity values increased. Besides, we can conclude long flow-path lengths or heterogeneity in pore system for soils containing $15 \%$ rock fragments. Relatively lower dispersivity values were estimated for the soil columns without rock fragments, therefore, demonstrating a relatively homogeneous porous medium.

\section{MOBILE-IMMOBILE PARTITION COEFFICIENT $(\beta)$}

In case of two-region model, Schulin et al. [20] explained the mobile-immobile partition coefficient $(\beta)$ parameter as representation of the solute portion present in the mobile region under equilibrium conditions. In our study, the mobile-immobile partition coefficient $(\beta)$ parameter was obtained by inversion simulation using two-region model, and the values for all columns are given in Table 2. $\beta$ of broadleaved forest soil columns equals to $0.79,0.66$, and $0.62 \mathrm{~cm}^{2} / \mathrm{h}$ in top soil layer $(0-20 \mathrm{~cm})$, and $0.61,0.58$, and $0.42 \mathrm{~cm}^{2} / \mathrm{h}$ in subsoil $(20-100$ $\mathrm{cm}$ ) for rock fragments content of $0 \%, 5 \%$, and $15 \%$, respectively, which is slightly different for that of coniferous forest soil columns which accounts 0.66 , 0.61 , and $0.39 \mathrm{~cm}^{2} / \mathrm{h}$ in upper layer, and $0.87,0.68$, and $0.63 \mathrm{~cm}^{2} / \mathrm{h}$ in subsoil for $0 \%, 5 \%$, and $15 \%$, rock fragments content, respectively. From these results, it is clear that the mobile-immobile partition coefficients values decreased with increasing volumetric content of rock fragments in most columns. The findings are directly in line with previous findings which found a decrease of $\beta$ with increased rock fragment content in soil [16] [43].

The possible reason is while the rock fragments occupying $5 \%$ or $15 \%$ of column volumes, they promote immobile regions due to their physical properties, and the fraction of solute present in the mobile region decreased, consequently, $\beta$ parameter values decreased. In the columns of soil-rock fragments mixture, the rock fragments represented immobile regions due to the lack of relative permeability. Consequently, the solute tended to concentrate in flow through the pore spaces between the rock fragments. The lower $\beta$ value means the increase of non-equilibrium [44], which indicates that the tracer movement is higher intensive and non-equilibrium in soil columns containing rock fragments. For that reason, we can conclude the presence of preferential flow in all broad-leaved and coniferous soil columns containing rock fragments, and the preferential flow is much more in the soil columns of huge content.

\section{MASS TRANSFER $(\omega)$}

The mass transfer coefficient, $\omega$, parameter is considered to describe the exchange of solute between mobile and immobile regions. Saturated column transport experiments were performed using an applied $\mathrm{KBr}$ pulse at constant pore 
water velocity through packed soils. Column mass transfer coefficients were determined from BTCs using CXTFIT 2 at rock fragments contents of $0 \%, 5 \%$, and $15 \%$. All the $\omega$ values for either upper or lower depth of both broad-leaved and coniferous forest soils were fitted as shown in Table 2. For a given rock fragments content, the mass transfer coefficient values show the evident dependence. Generally, the values decreased when rock content increased. As demonstrated in Table 2, based on broadleaved forest, mass transfer coefficients of upper layer were $0.33,0.025$ and 0.019 , then $0.015,0.014$ and 0.011 for lower soil layer for columns of rock fragment content of $0 \%, 5 \%$ and $15 \%$, respectively. On the side of coniferous forest soil, the mass transfer varied with increasing content of rock fragments in the column experiments yielding values of $0.025,0.015$, and 0.038 in upper layer soil, and 0.032, 0.041 and 0.015 In lower layer soil (at rock fragments content of $0 \%, 5 \%$ and $15 \%$, respectively).

In the two-region model, transport processes play a crucial role for $\mathrm{Br}$ movement. For instance, bromide transport was assumed to happen by convection and dispersion processes in the mobile water phase [56], while first-order process leads this tracer to enter and quit the immobile domain. Jiang et al. [57] demonstrated that $\omega$ can depend on the molecular diffusion coefficient, moreover, the distance and the cross-sectional area involved during diffusion. The mass transfer of bromide tracer between the mobile and immobile phases is controlled by diffusion process within the immobile water [56]. Due to decrease of macropores, immobile portion increases in soil-rock fragments mixture. The immobile water tortuosity is probably larger in soil containing rock fragments; hence diffusion and mass transfer are slower.

\section{Conclusions}

We investigated the effect of rock fragments content in forest soil when a bromide racer leaching through packed soil columns. The bromide breakthrough curves were fitted by two-region model. The results obtained from simulation showed that the values of dispersivity in soil containing rock fragments were higher than those derived from homogeneous soil in most columns. These results proved the influence of rock fragments on soil tortuosity and the distance traveled by the solute in soil columns. The mobile-immobile partition coefficient values tended to decrease with increasing any volumetric content of rock fragments (from $5 \%$ to $15 \%$ ). Furthermore, in many columns, mass transfer values declined.

Generally, the observed data showed that, even for homogeneous soil columns or heterogeneous soil-rock fragments mixture, breakthrough curves could be symmetrical and smooth. The two-region model demonstrated to be sufficiently accurate for solute transport simulation in the forest soil containing rock fragments. The tracer transport experiment proved that the addition of rock fragments can increase the transportation of solute in both broadleaved and coniferous forest soil columns. 
Rock fragments played a critical role on preferential transport of solute in forest soils, possibly through preferential flow pathways created by interfaces between soil and rock fragments. These results improve our understanding of the effects of rock fragments on solute leaching in forest soils. However, future studies need more detailed and systematic investigations since sizes and morphology of rock fragments in forest ecosystems is more complicated. Large contents and sizes of rock fragments should be considered for the reason that the Gongga Mountain and other most mountainous forest soils of China contain various rock fragments sizes such as gravels, medium stone, large stone, as well as boulders.

\section{Acknowledgements}

This study was financially supported by the Strategic Priority Research Program of the Chinese Academy of Sciences (Grant No. XDA23090202), the National Natural Science Foundation of China (41790431), and the Key Research Program of Frontier Sciences, Chinese Academy of Sciences (QYZDJ-SSW-DQC006).

\section{Conflicts of Interest}

The authors declare no conflicts of interest regarding the publication of this paper.

\section{References}

[1] Flury, M., Fluhler, H., Jury, W.A. and Leuenberger, J.J. (1994) Susceptibility of Soils to Preferential Flow of Water: A Field Study. Water Resources Research, 30, 19451954. https://doi.org/10.1029/94WR00871

[2] Wang, K. and Zhang, R. (2011) Heterogeneous Soil Water Flow and Macropores Described with Combined Tracers of Dye and Iodine. Journal of Hydrology, 397, 105-117. https://doi.org/10.1016/j.jhydrol.2010.11.037

[3] Zhang, Y., Zhang, M., Niu, J., Li, H., Xiao, R., Zheng, H. and Bech, J. (2016) Rock Fragments and Soil Hydrological Processes: Significance and Progress. Catena, 147, 153-166. https://doi.org/10.1016/j.catena.2016.07.012

[4] Zhang, Y., Niu, J., Zhang, M., Xiao, Z. and Zhu, W. (2016) Interaction between Plant Roots and Soil Water Flow in Response to Preferential Flow Paths in Northern China. Land Degradation \& Development, 28, 648-663. https://doi.org/10.1002/ldr.2592

[5] Wilson, G.V. and Luxmoore, R.J. (1988) Infiltration, Macroporosity and Mesoporosity Distributions on Two Forested Watersheds. Soil Science Society of America Journal, 52, 329-335. https://doi.org/10.2136/sssaj1988.03615995005200020005x

[6] Moret, D. and Arrúe, J.L. (2007) Characterizing Soil Water-Conducting Macro and Mesoporosity as Influenced by Tillage Using Tension Infiltrometry. Soil Science Society of America Journal, 71, 500-506. https://doi.org/10.2136/sssaj2006.0128

[7] Peng, X.D., Shi, D.M., Jiang, D., Wang, S.S. and Li, Y.X. (2014) Runoff Erosion Process on Different Underlying Surfaces from Disturbed Soils in the Three Gorges Reservoir Area, China. Catena, 123, 215-224.

https://doi.org/10.1016/j.catena.2014.08.012 
[8] Torri, D., Poesen, J., Monaci, F. and Busoni, E. (1994) Rock Fragment Content and Fine Soil Bulk Density. Catena, 23, 65-71. https://doi.org/10.1016/0341-8162(94)90053-1

[9] Shi, Z.J., Xu, L.H., Wang, Y.H., Yang, X.H., Jia, Z.Q., Guo, H., Xiong, W. and Yu, P.T. (2012) Effect of Rock Fragments on Macropores and Water Effluent in a Forest Soil in the Stony Mountains of the Loess Plateau, China. African Journal of Biotechnology, 11, 9350-9361. https://doi.org/10.5897/AJB12.145

[10] Poesen, J. and Lavee, H. (1994) Rock Fragments in Top Soils: Significance and Processes. Catena, 23, 1-28. https://doi.org/10.1016/0341-8162(94)90050-7

[11] Cousin, I., Nicoullaud, B. and Coutadeur, C. (2003) Influence of Rock Fragments on the Water Retention and Water Percolation in a Calcareous Soil. Catena, 53, 97-114. https://doi.org/10.1016/S0341-8162(03)00037-7

[12] Fu, S.H. (2005) Effect of Soil Containing Rock Fragment on Infiltration. Journal of Soil and Water Conservation, 19, 171-175.

[13] Cheng, G.W., Yu, X.X. and Zhao, Y.T. (2004) The Hydrological Cycle and Its Mathematical Models of Forest Ecosystems in Mountains. Beijing Science Press, Beijing.

[14] Vannoppen, W., Vanmaercke, M., De Baets, S. and Poesen, J. (2015) A Review of the Mechanical Effects of Plant Roots on Concentrated Flow Erosion Rates. EarthScience Reviews, 150, 666-678. https://doi.org/10.1016/j.earscirev.2015.08.011

[15] Meng, C., Niu, J., Yin, Z., Luo, Z., Lin, X. and Jia, J. (2018) Characteristics of Rock Fragments in Different Forest Stony Soil and Its Relationship with Macropore Characteristics in Mountain Area, Northern China. Journal of Mountain Science, 15, 519-531. https://doi.org/10.1007/s11629-017-4638-y

[16] Zhou, B.B., Shao, M.A., Wang, Q.J. and Yang, T. (2011) Effects of Different Rock Fragment Contents and Sizes on Solute Transport in Soil Columns. Vadose Zone Journal, 10, 386-393. https://doi.org/10.2136/vzj2009.0195

[17] Novák, V. and Hlaváčiková, H. (2019) Applied Soil Hydrology. Theory and Applications of Transport in Porous Media. Springer, Berlin.

https://doi.org/10.1007/978-3-030-01806-1

[18] Beckers, E., Pichault, M., Degré, A. and Garré, S. (2016) Characterization of Stony Soils' Hydraulic Conductivity Using Laboratory and Numerical Experiments. Soil, 2, 421-431. https://doi.org/10.5194/soil-2-421-2016

[19] Novák, V., Kňava, K. and Šimůnek, J. (2011) Determining the Influence of Stones on Hydraulic Conductivity of Saturated Soils, Using Numerical Method. Geoderma, 161, 177-181. https://doi.org/10.1016/j.geoderma.2010.12.016

[20] Schulin, R., Wierenga, P.J., Flühler, H. and Leuenberger, J. (1987) Solute Transport through a Stony Soil. Soil Science Society of America Journal, 51, 36-42. https://doi.org/10.2136/sssaj1987.03615995005100010007x

[21] Robinson, J.W. and Gale, J.E. (1990) A Laboratory and Numerical Investigation of Solute Transport in Discontinuous Fracture Systems. Ground Water, 28, 25-36. https://doi.org/10.1111/j.1745-6584.1990.tb02226.x

[22] Su, G.W., Geller, J.T., Pruess, K. and Hunt, J.R. (2001) Solute Transport along Preferential Flow Pathways in Unsaturated Fractures. Water Resources Research, 37, 2481-2491. https://doi.org/10.1029/2000WR000093

[23] Lee, H.B., Yeo, I.W. and Lee, K.K. (2014) Fluid Flow through Rough-Walled Rock Fractures with Hydrophobic Surfaces. Geoscience Journal, 18, 375-380.

https://doi.org/10.1007/s12303-014-0028-4 
[24] Matthäi, S.K., Nick, H.M., Pain, C. and Neuweiler, I. (2010) Simulation of Solute Transport through Fractured Rock: A Higher-Order Accurate Finite-Element Finite-Volume Method Permitting Large Time Steps. Transport in Porous Media, 83, 289-318. https://doi.org/10.1007/s11242-009-9440-Z

[25] Mahmoudzadeh, B., Liu, L.C., Moreno, L. and Neretnieks, L. (2016) Solute Transport through Fractured Rock: Radial Diffusion into the Rock Matrix with Several Geological Layers for an Arbitrary Length Decay Chain. Journal of Hydrology, 536, 133-146. https://doi.org/10.1016/j.jhydrol.2016.02.046

[26] Zhou, Q.L., Liu, H.H., Bodvarsson, G.S. and Oldenburg, C.M. (2003) Flow and Transport in Unsaturated Fractured Rock: Effects of Multiscale Heterogeneity of Hydrogeologic Properties. Journal of Contaminant Hydrology, 60, 1-3.

https://doi.org/10.1016/S0169-7722(02)00080-3

[27] Therrien, R. and Sudicky, E.A. (1996) Three-Dimensional Analysis of Variably-Saturated Flow and Solute Transport in Discretely-Fractured Porous Media. Journal of Contaminant Hydrology, 23, 1-44.

https://doi.org/10.1016/0169-7722(95)00088-7

[28] Wörman, A., Xu, S.L. and Dverstorp, B. (2003) Kinematic Analysis of Solute Mass Flows in Rock Fractures with Spatially Random Parameters. Journal of Contaminant Hydrology, 60, 163-191. https://doi.org/10.1016/S0169-7722(02)00088-8

[29] Hodgkinson, D., Benabderrahmane, H., Elert, M., Hautojärvi, A., Selroos, J.O., Tanaka, Y. and Uchida, M. (2009) An Overview of Task 6 of the Äspö Task Force: Modeling Groundwater and Solute Transport: Improved Understanding of Radionuclide Transport in Fractured Rock. Hydrogeology Journal, 17, 1035-1049. https://doi.org/10.1007/s10040-008-0416-9

[30] Zhang, Z.Y., Nemcik, J., Qiao, Q.Q. and Geng, X.Y. (2014) A Model for Water Flow through Rock Fractures Based on Friction Factor. Rock Mechanics and Rock Engineering, 48, 559-571. https://doi.org/10.1007/s00603-014-0562-4

[31] Liu, R.C., Jiang, Y.J., Li, B. and Wang, X.S. (2015) A Fractal Model for Characterizing Fluid Flow in Fractured Rock Masses Based on Randomly Distributed Rock Fracture Networks. Computers and Geotechnics, 65, 45-55. https://doi.org/10.1016/j.compgeo.2014.11.004

[32] Himmelsbach, T., Hötzl, H. and Maloszewski, P. (1998) Solute Transport Processes in a Highly Permeable Fault Zone of Lindau Fractured Rock Test Site. Groundwater, 36, 792-800. https://doi.org/10.1111/j.1745-6584.1998.tb02197.x

[33] Becker, M.W. and Shapiro, A.M. (2000) Tracer Transport in Fractured Crystalline Rock: Evidence of Non Diffusive Breakthrough Tailing. Water Resources Research, 36, 1677-1686. https://doi.org/10.1029/2000WR900080

[34] Bodin, J., Delay, F. and deMarsily, G. (2003) Solute Transport in a Single Fracture with Negligible Matrix Permeability: 1. Fundamental Mechanisms. Hydrogeology Journal, 11, 418-433. https://doi.org/10.1007/s10040-003-0268-2

[35] Rodrigues, N.E.V., de Lima, J.L.M.P. and Cruz, F.F. (2008) Solute Transport in Fractured Media-Analysis of Non-Reversibility in Tracer Tests. Nonlinear Processes in Geophysics, 15, 783-791. https://doi.org/10.5194/npg-15-783-2008

[36] Uchida, M., Dershowitz, W., Lee, G. and Shuttle, D. (2009) An Empirical Probabilistic Approach for Constraining the Uncertainty of Long-Term Solute Transport Predictions in Fractured Rock Using in Situ Tracer Experiments. Hydrogeology Journal, 17, 1093-1110. https://doi.org/10.1007/s10040-008-0417-8

[37] Day-Lewis, F.D., Lane Jr., J.W., Harris, J.M. and Gorelick, S.M. (2003) Time-Lapse Imaging of Saline-Tracer Transport in Fractured Rock Using Difference-Attenua- 
tion Radar Tomography. Water Resources Research, 39, 1290-1304.

https://doi.org/10.1029/2002WR001722

[38] Roubinet, D., de Dreuzy, J.R. and Tartakovsky, D.M. (2012) Semi-Analytical Solutions for Solute Transport and Exchange Infractured Porous Media. Water Resources Research, 48, 1542-1552. https://doi.org/10.1029/2011WR011168

[39] Bodin, J., Porel, G., Delay, F., Ubertosi, F., Bernard, S. and de Dreuzy, J.R. (2007) Simulation and Analysis of Solute Transport in 2D Fracture/Pipe Networks: The SOLFRAC Program. Journal of Contaminant Hydrology, 89, 1-28. https://doi.org/10.1016/j.jconhyd.2006.07.005

[40] Lipson, D.S., McCray, J.E. and Thyne, G.D. (2007) Using PHREEQC to Simulate Solute Transport in Fractured Bedrock. Groundwater, 45, 468-472. https://doi.org/10.1111/j.1745-6584.2007.00318.x

[41] Natarajan, N. and Suresh Kumar, G. (2010) Solute Transport in a Coupled Fracture Matrix System with Sinusoidal Fracture Geometry. International Journal of Engineering Science and Technology, 2, 1886-1992.

[42] Vilarrasa, V., Koyama, T., Neretnieks, I. and Jing, L. (2011) Shear-Induced Flow Channels in a Single Rock Fracture and Their Effect on Solute Transport. Transport in Porous Media, 87, 503-523. https://doi.org/10.1007/s11242-010-9698-1

[43] Zhou, B.B., Shao, M.A. and Shao, H.B. (2009) Effects of Rock Fragments on Water Movement and Solute Transport in a Loess Plateau Soil. Comptes Rendus Geoscience, 341, 462-472. https://doi.org/10.1016/j.crte.2009.03.009

[44] Lei, W., Tang, X. and Zhou, X. (2019) Quantifying Dynamic Desorption of 3,5,6Trichloro-2-pyridinol in Loamy Farmland Soils. Environmental Science and Pollution Research, 26, 30782-30793. https://doi.org/10.1007/s11356-019-06233-4

[45] van Genuchten, M.Th. and Wierenga, P.J. (1986) Mass Transfer Studies in Sorbing Porous Media: II. Experimental Evaluation with Tritium. Soil Science Society of America Journal, 41, 272-277. https://doi.org/10.2136/sssaj1977.03615995004100020022x

[46] Tang, G., Mayes, M.A., Parker, J.C., Yin, X.L., Watson, D.B. and Jardine, P.M. (2009) Improving Parameter Estimation for Column Experiments by Multi-Model Evaluation and Comparison. Journal of Hydrology, 376, 567-578. https://doi.org/10.1016/j.jhydrol.2009.07.063

[47] Hu, Z., Wang, G. and Sun, X. (2017) Precipitation and Air Temperature Control the Variations of Dissolved Organic Matter along an Altitudinal Forest Gradient, Gongga Mountains, China. Environmental Science and Pollution Research, 24, 10391-10400. https://doi.org/10.1007/s11356-017-8719-9

[48] Wu, Y.H., Li, W., Zhou, J. and Cao, Y. (2013) Temperature and Precipitation Variations at Two Meteorological Stations on Eastern Slope of Gongga Mountain, SW China in the Past Two Decades. Journal of Mountain Science, 10, 370-377. https://doi.org/10.1007/s11629-013-2328-y

[49] Walkley, A. and Black, I.A. (1934) An Examination of the Degthareff Method for Determining Soil Organic Matter and a Proposed Modification of the Chromic Acid Titration Method. Soil Science, 37, 29-38. https://doi.org/10.1097/00010694-193401000-00003

[50] Gee, G.W. and Or, D. (2002) Particle Size Analysis. In: Dane, J.H. and Topp, G.C., Eds., Methods of Soil Analysis, Part 4: Physical Methods, Number 5 in the Soil Science Society of America Book Series, SSSA, Madison, 255-293.

[51] Thomas, G.W. (1996) Soil pH and Soil Acidity. In: Sparks, D.L., Ed., Methods of Soil Analysis. Part 3. Chemical Methods, SSSA Book Ser. 5, SSSA and ASA, Madi- 
son, 475-490. https://doi.org/10.2136/sssabookser5.3.c16

[52] Musa, J.J. and Gupa, Y.U. (2019) An Overview of Methods Used in the Determination of Soil Hydraulic Conductivity. Al-Hikmah Journal of Pure \& Applied Sciences, 7, 22-30.

[53] Toride, N., Leij, F.J. and van Genuchten, M.Th. (1995) The CXTFIT Code for Estimating Transport Parameters from Laboratory or Field Tracer Experiments. US Salinity Laboratory.

[54] Nkedi-Kizza, P., Biggar, J.M., van Genuchten, M.Th. and Wierenga, P.J. (1983) Modeling Tritium and Chloride Transport through an Aggregated Oxisol. Water Resources Research, 19, 691-700. https://doi.org/10.1029/WR019i003p00691

[55] Russo, D.L. (1983) Leaching Characteristics of a Stony Desert Soil. Soil Science Society of America Journal, 47, 431-438. https://doi.org/10.2136/sssaj1983.03615995004700030008x

[56] Poulsen, T.G., Moldrup, P., de Jonge, L.W. and Komatsu, T. (2006) Colloid and Bromide Transport in Undisturbed Soil Columns: Application of Two-Region Model. Vadose Zone Journal, 5, 649-656. https://doi.org/10.2136/vzj2005.0068

[57] Jiang, Y.L., Zhou, B.B., Shao, M.A. and Wang, Q.J. (2013) Experimental Study on Preferential Solute Transport in a Loess Plateau Soil. Australian Journal of Crop Science, 7, 93-98 